\title{
Round scallops and square meshes: a comparison of four codend types on the catch rates of target species and by-catch in the Queensland (Australia) saucer scallop (Amusium balloti) trawl fishery
}

\author{
Anthony J. Courtney A,D, Matthew J. Campbell ${ }^{\mathrm{A}}$, Darren P. Roy ${ }^{\mathrm{A}}$, \\ Mark L. Tonks ${ }^{\mathrm{A}, \mathrm{B}}$, Keith E. Chilcott ${ }^{\mathrm{A}}$ and Peter M. Kyne ${ }^{\mathrm{C}}$ \\ ${ }^{A}$ Queensland Department of Primary Industries and Fisheries, Southern Fisheries Centre, \\ PO Box 76, Deception Bay, Qld 4508, Australia. \\ BPresent address: CSIRO Marine and Atmospheric Research, PO Box 120, Cleverland, \\ Qld 4163, Australia. \\ ${ }^{C}$ School of Biomedical Sciences, University of Queensland, St. Lucia, Qld 4072, Australia. \\ ${ }^{\mathrm{D} C o r r e s p o n d i n g ~ a u t h o r . ~ E m a i l: ~ t o n y . c o u r t n e y @ d p i . q l d . g o v . a u ~}$
}

\begin{abstract}
Concern over the amount of by-catch from benthic trawl fisheries and research into the problem have increased in recent years. The present paper demonstrated that by-catch rates in the Queensland (Australia) saucer scallop (Amusium balloti) trawl fishery can be reduced by $77 \%$ (by weight) using nets fitted with a turtle excluder device (TED) and a square-mesh codend, compared with a standard diamond-mesh codend with no TED. This large reduction was achieved with no significant effect on the legal size scallop catch rate and $39 \%$ fewer undersize scallops were caught. In total, 382 taxa were recorded in the by-catch, which was dominated by sponges, portunid crabs, small demersal and benthic fish (e.g. leatherjackets, stingerfish, bearded ghouls, nemipterids, longspine emperors, lizard fish, triggerfish, flounders and rabbitfish), elasmobranchs (e.g. mainly rays) and invertebrates (e.g. sea stars, sea urchins, sea cucumbers and bivalve molluscs). Extremely high reductions in catch rate (i.e. $\geq 85 \%$ ) were demonstrated for several by-catch species owing to the square-mesh codend. Square-mesh codends show potential as a means of greatly reducing by-catch and lowering the incidental capture and mortality of undersize scallops and Moreton Bay bugs (Thenus australiensis) in this fishery.
\end{abstract}

Additional keywords: benthic impacts, drag, Great Barrier Reef, selectivity, trawl net.

\section{Introduction}

Research on by-catch from commercial fisheries, and its mitigation, has increased over the last two decades (Andrew and Pepperell 1992; Alverson et al. 1994; Robins et al. 1999; Broadhurst 2000; Hall et al. 2000; Hall and Mainprise 2005). Alverson et al. (1994) estimated that $\sim 27$ million tonnes of by-catch was produced globally by commercial fisheries annually, but the more recent estimate by Kelleher (2005) was significantly less at 7.3 million tonnes, with over $50 \%$ attributed to trawl fisheries for shrimp (i.e. prawns) and demersal finfish. Although most of the difference between these two estimates was due to the methods used in their calculation, total global by-catch appears to have declined in recent years owing to (1) improved selectivity of fishing gears, (2) improved regulations and enforcement, (3) increased utilisation of catches for both human and animal food and (4) the development of processing technologies and markets for lower-value catch (Kelleher 2005). Despite the decline, Hall and Mainprise (2005) concluded that further significant reductions, in the order of $25 \%$ to $64 \%$, could be achieved if fishing fleets adopted the gear modifications that have been demonstrated in experimental studies.
The Queensland east coast otter trawl fishery (QECOTF) has the largest benthic trawl fleet in Australia and, as such, the amount of by-catch produced annually is substantial. In the late 1990s, it was estimated to exceed $25000 \mathrm{t}$ annually (Robins and Courtney 1998). The impact of trawling by this fishery on benthic habitats and by-catch species' populations is particularly contentious because $\sim 70 \%$ of the fishery's catch and effort occur in the Great Barrier Reef Marine Park, which has World Heritage status. In 2007, the fishery consisted of 480 licensed otter trawl vessels that were allocated $\sim 75000$ boat nights of fishing effort, although a small proportion of this effort is latent or unused. The fishery targets penaeid prawns (Penaeus spp., Melicertus spp. and Metapenaeus spp.), saucer scallops (Amusium balloti), scyllarid lobsters (commonly known as Moreton Bay bugs; Thenus australiensis and T. parindicus) and squid (Loligo spp.), and can also retain incidental catches of several other species (i.e. byproduct). Approximately $9000 \mathrm{t}$ of catch is marketed annually, at a value of AU\$101-139 million (Kerrigan et al. 2004). In the period 2000-2002, the fisheries managers introduced a mandatory measure requiring both a turtle excluder device (TED) and a by-catch reduction device (BRD) to be installed in every otter 
trawl net. TEDs were introduced to reduce the incidental capture of turtles (Robins 1995), but have also been shown to reduce bycatch of other large fauna, including sharks, rays and sponges (Brewer et al. 1998, 2006). BRDs were introduced to reduce the remaining by-catch, which is characterised by hundreds of species of small fish and invertebrates (Jones and Derbyshire 1988; Watson and Goeden 1989; Watson et al. 1990; Courtney et al. 2006). Currently, there are seven recognised BRDs that fishers can choose from.

The saucer scallop fishery is a commercially important sector within the QECOTF. From 1989 to 1996, the average annual reported weight of scallop meat was $962 \mathrm{t}$ (O'Neill et al. 2005), valued at approximately AU $\$ 30$ million. Annual levels of scallop fishing effort were relatively stable between 1990 and 2001, averaging 13583 boat nights per year, but have declined in recent years in response to management changes. Although there is no specific licence requirement (i.e. all 480 operators can trawl for scallops), management measures for the scallop fishery include (1) the use of rotational spawning stock closures, (2) seasonally changing minimum legal sizes and (3) a minimum mesh size of $75 \mathrm{~mm}$, which fishers apply to conventional diamond-mesh nets (Dredge 1994). There is scant information on the amount and composition of by-catch in the scallop fishery, although observations during fisheryindependent surveys (Dichmont et al. 2000; Barker et al. 2004) indicate that the by-catch weight greatly exceeds the scallop catch. Most scallop fisheries use benthic dredges and, as such, their by-catch is dominated by epibenthic invertebrates (Currie and Parry 1994; DuPaul et al. 1996; Veale et al. 2001), but because the Queensland fishery uses otter trawls, the composition of the by-catch may be considered atypical. DuPaul et al. (1996) identified modifications to scallop dredge gear for reducing by-catch of finfish, undersize scallops and damage to by-catch species, but these approaches are not applicable to otter trawl gear.

One approach that may be suitable for reducing by-catch in the scallop fishery is the deployment of square-mesh codends. These are codends constructed largely of meshes that are hung on the bar, resulting in a matrix of squares that remain open, thus allowing small by-catch species to escape (Eayrs et al. 1997). Conventional diamond meshes close up when stretched or under load, greatly reducing escapement (Fonteyne and M'Rabet 1992). Compared with standard diamond-mesh codends, squaremesh codends have been shown to reduce by-catch in several fish and invertebrate fisheries with minimal or no loss of the targeted catch (Suuronen and Millar 1992; Thorsteinsson 1992; Broadhurst et al. 1999, 2004; Macbeth et al. 2005; Bahamon et al. 2006). Square-mesh codends appear to have potential in the Queensland scallop fishery as a means of reducing bycatch because (1) much of the by-catch comprises relatively small finfish and invertebrates that could escape through the square meshes and (2) provided the squares are smaller than the minimum legal size of the scallops, there should be minimal loss of targeted catch. Another attractive feature of square-mesh codends is that, unlike most BRDs that rely on by-catch being able to locate the escape hole or section and then swim through it, square-mesh codends surround the by-catch with multiple points of escape, which many species can pass through, or simply fall through.
The present paper evaluates the potential of square-mesh codends in the Queensland scallop fishery as a by-catch reduction device. Because all otter trawlers in the fleet must now have a TED as well as a BRD in every net, the study quantified the effects of the square-mesh codend with and without a TED. Several hypotheses were tested including that (1) catch rates of by-catch, scallops, Moreton Bay bugs and individual by-catch species, (2) length of by-catch species and (3) by-catch assemblages were independent of codend type.

\section{Materials and methods}

In the present paper, 'by-catch' is defined as that portion of the catch that is returned to the sea. Our definition is similar to the FAO Fisheries Report No. 547 (FAO 1996) definition of discards, except that ours includes calcareous rubble, algae and seagrass as well as animals.

\section{Research charter design}

The effects of the square-mesh codend were evaluated during a purposely designed 8-night research charter in October 2002 in the scallop fishery. To ensure the by-catch composition and scallop catch rates were representative of the fishery, all trawl sampling was conducted in areas that received medium to high levels of trawl fishing effort for the months of October to December, based on logbook data from 1996 to 2001. The distribution of sample sites was stratified so that areas that received high levels of effort received more sampling than medium-effort areas. A commercial trawler and her crew, who allocate a significant proportion of their annual fishing effort to the scallop fishery, were hired to undertake the charter, in conjunction with project research staff on board.

In the scallop fishery, most vessels tow either three nets (i.e. one net on both the port and starboard sides and a third net from the stern, referred to as triple gear) or four nets (two nets towed on each of the port and starboard sides, referred to as quad gear) (O'Neill et al. 2005). Quad gear was preferred for research purposes because it facilitated comparison of more (i.e. four) codend types simultaneously at each site. The four codend types that were compared were:

1 88.9-mm (3 1/2 inch) standard diamond-mesh codend with no TED (referred to herein as the 'standard codend' or the 'standard net');

2 88.9-mm (3 1/2 inch) standard diamond-mesh codend with TED;

3 101.6-mm (4 inch) square-mesh codend; and

4 101.6-mm (4 inch) square-mesh codend with TED.

The codends were sewn onto new six-fathom (10.97 m), twoseam Florida Flyer nets with standard diamond mesh. This net type is commonly used throughout the fishery and new nets were deployed to minimise between-net variation that may have been due to wearing, stretching or repairs.

The standard 88.9-mm diamond-mesh codend was 33 meshes long, 60 meshes round and constructed from 6-mm braided polyethylene (Fig. 1). The 101.6-mm square-mesh codend was also constructed of 6-mm braided polyethylene, 36 bars round and 40 bars long (Fig. 1 $a, b$ ). When hung on the bar, it produced a matrix of open square meshes that were $50.8 \mathrm{~mm}$ by 
(a)

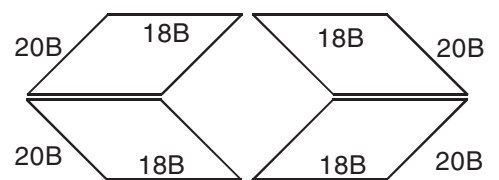

(b)
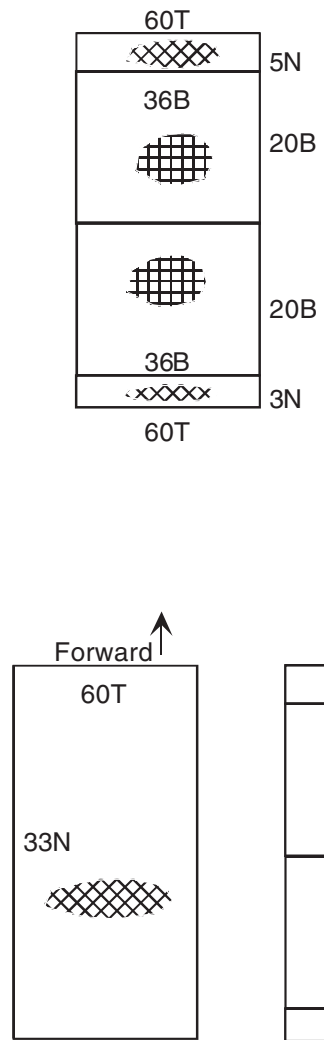

Standard codend

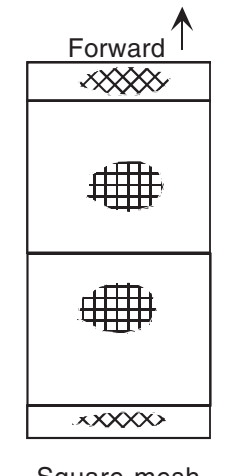

Square-mesh
codend BRD (c)

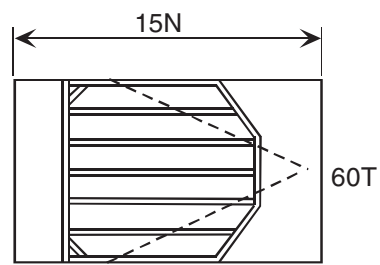

(d)
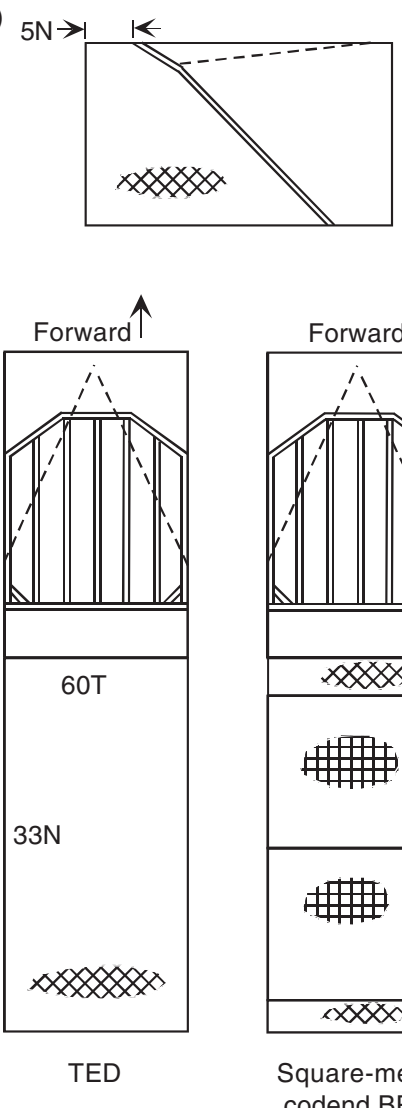

Fig. 1. (a) The square-mesh codend was constructed using four identical pieces of 4-inch (100-mm), 6-mm polyethylene mesh. Each piece of mesh was 18 bars wide and 20 bars long and, sewn together, resulted in a single tube of mesh 36 bars round by 40 bars long. (b) Plan view (i.e. from above) of the square-mesh codend by-catch reduction device (BRD). A small length of diamond-mesh was sewn on the aft edge of the square-mesh codend to facilitate the addition of drawstrings. Similarly, a section of diamond-mesh was added to the forward edge of the square-mesh codend to allow the codend to be sewn onto the nets used during the charter. (c) Plan view (i.e. from above) of the turtle exclusion device (TED). (d) Elevation (i.e. from the side) of the TED. Plan views of the four codend types are provided in the lower half of the figure. Diagrams are not drawn to scale.

$50.8 \mathrm{~mm}$. A short section of diamond-mesh, 60 meshes round and 5 meshes long, constructed from the same material as that used in the square-mesh codend, was sewn onto the forward end to attach lifting points for the retrieval lines. Another short section of the $88.9-\mathrm{mm}$ diamond-mesh, 36 meshes round and 3 meshes long, was sewn onto the aft end so that the drawstring could be attached. Four lengths of $12-\mathrm{mm}$ polyethylene rope were selvedged along four sides of the square-mesh codend to take the weight of the accumulated catch, thereby reducing mesh distortion and knot slippage. The standard 88.9-mm mesh codend and the 101.6-mm square-mesh codend had the same total lengths. Inserting the TED section extended the codends by
15 meshes or $\sim 1.3 \mathrm{~m}$. Rubber chafing mats were attached to all codends. The TED used throughout the charter was a single hard grid constructed from 25-mm (1 inch) aluminium tubing, 800$\mathrm{mm}$ wide, 1080-mm high, with a bar space of $120 \mathrm{~mm}$ and sewn into a codend extension at $60^{\circ}$ in top-shooter mode (Fig. $1 c, d$ ). The deflector bars were bent by $30^{\circ} \sim 150 \mathrm{~mm}$ ( 6 inches) from the top of the grid.

At each site, the four nets were towed simultaneously along the bottom for precisely two nautical miles $(3704 \mathrm{~m})$, measured using a global positioning system. Trawl speed was fixed at 2.3 knots and the nets were towed in a straight line so that each net swept the same sized area along the bottom. Given the spatial 
distribution of the fishery, 'steaming' time between sites, and the time required to winch away, retrieve nets and process the catch, it was estimated that 7-8 sites could be trawled each night (note the scallop fishery is fished at night and daylight trawling is prohibited)

\section{Sampling the catch}

After each site was trawled, all four nets were retrieved and their codends were emptied onto a partitioned sorting tray to keep their contents separated. The following procedure was applied to the catch of each net. Large by-catch species (i.e. weighing more than $\sim 10 \mathrm{~kg}$ ) and species of conservation interest that could not be retained were identified, weighed, recorded and released. These species included large sharks, rays, puffer fish and sponges and were collectively referred to as 'large by-catch fauna'. The scallop catch was weighed and recorded and, with the exception of large catches (i.e. $>10 \mathrm{~kg}$ ), all scallops were retained, labelled, frozen and later processed in the laboratory. When large catches of scallops were obtained, a sub-sample of $\sim 10 \mathrm{~kg}$ was retained, labelled, frozen and later processed in the laboratory. Moreton Bay bugs (T. australiensis) are a commercially valuable component of the catch in the scallop trawl fishery and were removed from the catch, labelled, frozen and later processed in the laboratory. The remaining by-catch was placed in plastic baskets, weighed to the nearest $0.1 \mathrm{~kg}$ and recorded. A $10-\mathrm{kg}$ (approximate) sub-sample of the by-catch was then obtained by scooping it into a labelled cardboard carton, frozen on board and later processed in the laboratory. If the by-catch was less than $\sim 10 \mathrm{~kg}$, then it was retained in its entirety.

\section{Laboratory processing}

In the laboratory, the weight and shell height ( $\mathrm{SH})$ of every scallop were measured and recorded to the nearest $0.1 \mathrm{~g}$ and $0.1 \mathrm{~mm}$ respectively. Moreton Bay bugs were measured to the nearest $0.1 \mathrm{~mm}$ carapace width $(\mathrm{CW})$. Each individual in the by-catch sub-samples was identified to species level and counted and the total weight of each species was measured and recorded. Length measures for the by-catch species (standard length or total length for fish, carapace length or width for crustaceans, disc width or total length for elasmobranchs, total length for echinoderms and shell length for molluscs) were obtained from a maximum of 20 individuals of each species from each sub-sample. Whenever the scallop catch or by-catch was sub-sampled at sea, the precise weight of the sub-sample was determined in the laboratory by summing the weights of the individuals contained within it.

\section{Calculating catch rates of scallops and by-catch species}

All catch rates were converted to weight ( $\mathrm{g}$ or $\mathrm{kg}$ ) per swept area trawled (ha). Because the weight of individual by-catch species caught in each net during each trawl was not always directly measured (i.e. large catches of by-catch were sub-sampled), it was estimated using $\hat{W}_{s}=W_{s} \times\left(T B W_{s} / S S W_{s}\right)$, where $\hat{W}_{s}$ is the estimate of the weight of species $s$ caught in the net during the trawl, $W_{s}$ is the weight of species $s$ in the sub-sample of the net from the trawl, $T B W_{S}$ is the total by-catch weight (less large bycatch fauna, defined above) from the net during the trawl and $S S W_{S}$ is the weight of the sub-sample of by-catch taken from the net during the trawl.
The area $A$ swept by each net during each trawl was constant and estimated using $A=(H \times F \times D) / 10000$, where $H$ was the headline length of the net $(10.97 \mathrm{~m}), F$ was the net spread factor (0.70; from Sterling (2005)) and $D$ was the distance trawled (two nautical miles is $3704 \mathrm{~m}$ ). Division by 10000 converts the area from square metres to hectares. Using this formula, each net swept 2.84 ha along the bottom during each trawl. Catch rate was then derived by dividing the weight $\hat{W}_{s}(\mathrm{~kg}$ or g) by the area swept ( $A=2.84 \mathrm{ha})$.

\section{Statistical design and analyses}

Towing quad gear (i.e. four nets) facilitated a complete block design (Montgomery 1997) where all four codend types could be tested simultaneously at each site. To account for possible effects due to the position of the net, the codends were cut off and sewn onto a net in a different position after each night of sampling. The protocol for determining which codend type was sampled in which net position was predetermined and randomised such that each codend was tested in each position for 2 nights (Table 1).

Generalised linear modelling (GLM) using GENSTAT (2007) statistical software was used to examine the effect of codend type on the catch rate of by-catch, scallops and Moreton Bay bugs. Trawl site was considered as a categorical blocking term. Model distributions and link functions included normal distribution with identity link, binomial distribution with logit link and gamma distribution with logarithm link functions. Three data transformations were trialled when normal distributions were used: power, log and square root. The best model goodness-offit was obtained by checking for normality and constant variance of the standardised residuals. If these assumptions were not met, then the distribution type or transformation was changed until they were satisfied. The models took the following general form:

$$
\begin{aligned}
& U=\beta_{0}+\beta_{1}\left(\text { trawl }_{\text {site }_{1-n}}\right)+\beta_{2}\left(\text { net } \text { position }_{1-4}\right) \\
& +\beta_{3}\left(\text { codend type } \text { }_{1-4}\right)+\varepsilon
\end{aligned}
$$

where $U$ was the predicted catch rate for (1) total by-catch weight, (2) individual by-catch species weight or (3) targeted scallop weight from each trawl, $\beta_{0}$ was a scalar parameter that was estimated and $\beta_{1}, \beta_{2}$ and $\beta_{3}$ were vector parameters that were estimated and $\varepsilon$ was the error term. Only estimates of $\beta_{3}$ are presented because this parameter quantifies the codend-type effect. For purposes of interpretation, the $\beta_{3}$ parameter estimates were proportionally scaled so that they could be compared with a standard codend parameter value of 1.0. Factors were added in the model in a stepwise manner and when a significant codend effect was detected, $t$-tests for all pairwise differences of model means were undertaken using GENSTAT's RPAIR procedure.

A similar model was developed to examine the effect of codend type on the length of by-catch species. Model distributions and link functions were the same as those above and all pairwise differences in model mean lengths were compared using $t$-tests.

Multidimensional scaling (MDS) was used to test the hypotheses that by-catch community structure was independent of depth, latitude and codend type. The statistical software package PRIMER (Clarke and Warwick 1994) was used to undertake the analyses, which were based on a species-site matrix. Bycatch species catch rates $\left(\mathrm{g} \mathrm{ha}^{-1}\right)$ were standardised such that 
Table 1. The sampling protocol for codend type and net position applied during the charter

\begin{tabular}{|c|c|c|c|c|}
\hline \multirow{2}{*}{$\begin{array}{l}\text { Night of } \\
\text { sampling }\end{array}$} & \multicolumn{4}{|c|}{ Net position } \\
\hline & Port inner net & Port outer net & Starboard inner net & Starboard outer net \\
\hline $1(7)$ & TED & $\begin{array}{l}\text { Square-mesh codend BRD } \\
\text { with TED }\end{array}$ & Standard codend & Square-mesh codend BRD \\
\hline $2(8)$ & Standard codend & Square-mesh codend BRD & TED & $\begin{array}{l}\text { Square-mesh codend BRD } \\
\text { with TED }\end{array}$ \\
\hline $3(6)$ & Square-mesh codend BRD & Standard codend & $\begin{array}{l}\text { Square-mesh codend BRD } \\
\text { with TED }\end{array}$ & TED \\
\hline $4(8)$ & $\begin{array}{l}\text { Square-mesh codend BRD } \\
\text { with TED }\end{array}$ & TED & Square-mesh codend BRD & Standard codend \\
\hline $5(7)$ & TED & Standard codend & Square-mesh codend BRD & $\begin{array}{l}\text { Square-mesh codend BRD } \\
\text { with TED }\end{array}$ \\
\hline $6(9)$ & Standard codend & TED & $\begin{array}{l}\text { Square-mesh codend BRD } \\
\text { with TED }\end{array}$ & Square-mesh codend BRD \\
\hline $7(7)$ & Square-mesh codend BRD & $\begin{array}{l}\text { Square-mesh codend BRD } \\
\text { with TED }\end{array}$ & TED & Standard codend \\
\hline $8(7)$ & $\begin{array}{l}\text { Square-mesh codend BRD } \\
\text { with TED }\end{array}$ & Square-mesh codend BRD & Standard codend & TED \\
\hline
\end{tabular}

BRD, by-catch reduction device; TED, turtle exclusion device.

${ }^{\mathrm{A}}$ The number of sites trawled each night is shown in brackets.

all samples totalled to $100 \%$ and then fourth-root transformed. Bray-Curtis similarity indices were then calculated to examine the similarity between each pair of samples. The PRIMER routine ANOSIM (analysis of similarities) was applied to test for differences between groups, whereas a second routine SIMPER (similarity percentages) was used to examine the contribution of species to the average dissimilarity between groups. The number of factor levels was reduced by rounding depths to the nearest $10 \mathrm{~m}$ and latitude to the nearest 0.5 degree. MDS was carried out on species that were present in at least $5 \%$ of samples to avoid the species-site matrix table from being dominated by zeros.

\section{Results}

In total, 59 sites were trawled (Fig. 2) over the 8 nights, resulting in 236 (i.e. 59 sites $\times 4$ nets) measurements and subsamples of by-catch and scallops. The average trawl duration was 50.8 (s.e. 0.5) minutes and the number of sites sampled each night varied between six and nine (Table 1). The total weight of by-catch (i.e. including large by-catch fauna) and scallops (including all size classes) caught during the charter were $6212.4 \mathrm{~kg}$ and $1333.1 \mathrm{~kg}$ respectively. Three hundred and eightytwo taxa were identified in the by-catch. Approximately $64 \%$ of the by-catch weight was attributed to large by-catch fauna, of which large sponges (Porifera) comprised 92\%. The remaining $8 \%$ was attributed to a small number of relatively large sharks, rays, croakers, lutjanids and pufferfish and included the eastern shovelnose ray (Aptychotrema rostrata), leopard whipray (Himantura undulata), blue-spotted stingray (Dasyatis kuhlii), whitespotted wedgefish (Rhynchobatus australiae) and starry pufferfish (Arothron stellatus).

The remaining $36 \%$ of the by-catch was composed of small species of fish and invertebrates, calcareous rubble and seagrass, with eight species accounting for over $50 \%$ of the weight: the longspine emperor (Lethrinus genivittatus 12\%), red portunid crab (Portunus rubromarginatus 7\%), undersize blue swimmer crabs (Portunus pelagicus 7\%), Caledonian stinger (Inimicus caledonicus 6\%), threadfin bream (Nemipterus theodorei 5\%), lizard fish (Saurida grandisquamis 5\%), many-striped pufferfish (Anchisomus multistriatus 4\%) and a sponge (Callyspongia sp. $4 \%$ ). Forty-nine taxa accounted for $90 \%$ of the weight. No turtles were caught during the charter.

\section{Effects of codend type on by-catch and scallops}

The effects of codend type on by-catch rates were modelled using two response variables. The first was total by-catch weight including large by-catch fauna. The second was by-catch weight excluding large fauna; this second variable was designed to remove the effect of a single or few large individuals (i.e. a large sponge, shark or ray) heavily influencing the results. The observed mean catch rate for total by-catch from the standard net was $15.89 \mathrm{~kg} \mathrm{ha}^{-1}$. Total by-catch rates differed significantly between codend types (deviance ratio $(D R)=33.02$, d.f. $=$ $3,174, P<0.001)$. The TED by itself reduced the catch rate of total by-catch by $47 \%$ ( $\beta_{3}$ parameter estimate of 0.53 , Table 2$)$ compared with the standard codend. The square-mesh codend by itself reduced the total by-catch rate by $40 \%$ ( $\beta_{3}$ parameter estimate of 0.60 , Table 2 ). When both devices were used together, they reduced total by-catch rate by $77 \%$ ( $\beta_{3}$ parameter estimate of 0.23 , Table 2). All of the above reductions were significant $(P<0.05$, Table 2$)$ compared with the standard net according to $t$-tests on the modelled means.

The observed mean catch rate of by-catch from the standard net, excluding the large fauna, was $4.59 \mathrm{~kg} \mathrm{ha}^{-1}$ (Table 2). Catch rates of by-catch, excluding large fauna, differed significantly between codend types (DR $=46.85$, d.f. $=3,174, P<0.001)$. The TED by itself had no significant effect on the by-catch excluding large fauna, but catch rates fell significantly in nets with the square-mesh codends. A $56 \%$ reduction was obtained in the net with the square-mesh codend by itself $\left(\beta_{3}\right.$ parameter estimate of 0.44 , Table 2 ) and the net with both the TED and 


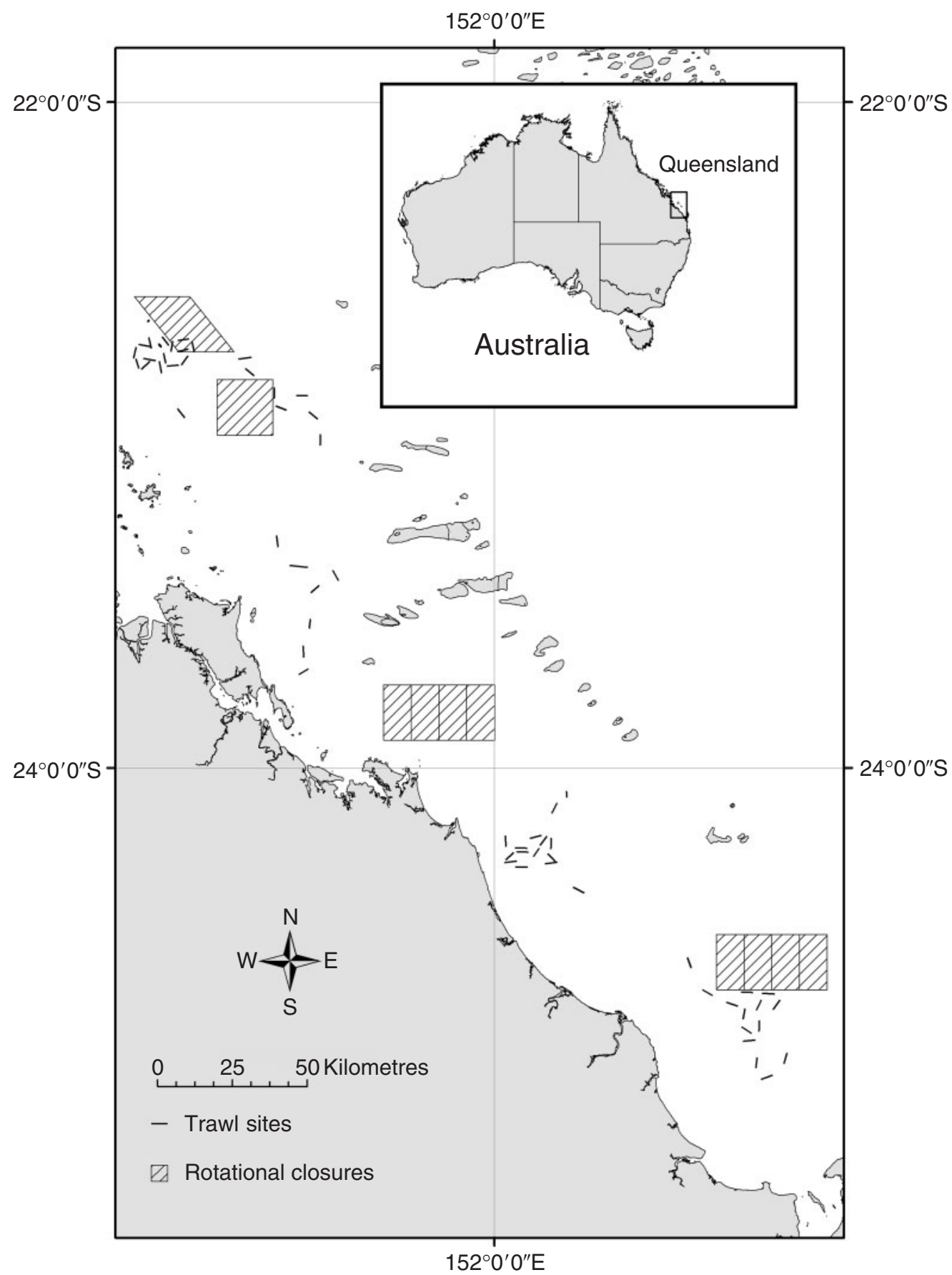

Fig. 2. Location of the 59 sites in the Queensland saucer scallop fishery that were trawled during the charter. Each site was two nautical miles long. Four nets were towed simultaneously at each site, each with a different codend type, resulting in 236 ( 59 sites $\times 4$ nets) measurements of by-catch and scallop catch rates.

square-mesh codend produced a $54 \%$ reduction $\left(\beta_{3}\right.$ parameter estimate of 0.46 , Table 2).

None of the codend types had a significant effect on the mean catch rate of legal size scallops $(\geq 95 \mathrm{~mm} \mathrm{SH})$ (Variance Ratio $(V R)=0.83$, d.f. $=3,174, P=0.480$, Table 2 ). Catch rates of undersize scallops, however, differed significantly between codend types $(\mathrm{VR}=12.32$, d.f. $=3,171, P<0.001)$. The TED by itself had no significant effect on the catch rate of undersize scallops ( $\beta_{3}$ parameter estimate of 0.95 , Table 2 ). The squaremesh codend by itself reduced the mean catch rate of undersize scallops by $15 \%$ ( $\beta_{3}$ parameter estimate of 0.85 , Table 2$)$ and when the TED and square-mesh codend were used together, they produced a $32 \%$ reduction $\left(\beta_{3}\right.$ parameter estimate of 0.68 , Table 2) compared with the standard net. Because most undersize 
Table 2. Effects of codend type on the catch rates of by-catch and scallops based on 236 measures of by-catch and scallop catches (59 sites trawled $\times 4$ nets)

Generalised linear modelling was used to quantify the effects. Significant differences between codends $(P<0.05)$ are shown in bold and identified by different letters (A, B or C). Parameter estimates were proportionally scaled so they can be compared with a standard net parameter value of 1 . Standard errors in parentheses

\begin{tabular}{|c|c|c|c|c|c|}
\hline \multirow[t]{2}{*}{ Catch component } & \multirow{2}{*}{$\begin{array}{c}\text { Mean observed } \\
\text { catch rate }\left(\mathrm{kg} \mathrm{ha}^{-1}\right) \text { in } \\
\text { standard net codend }\end{array}$} & \multicolumn{3}{|c|}{ Codend type parameter $\left(\beta_{3}\right)$ estimate } & \multirow[t]{2}{*}{ Distribution type } \\
\hline & & TED only & $\begin{array}{c}\text { Square-mesh } \\
\text { codend BRD only }\end{array}$ & $\begin{array}{l}\text { Square-mesh } \\
\text { codend BRD and } \\
\text { TED together }\end{array}$ & \\
\hline Total by-catch & $15.89(2.48) \mathrm{A}$ & $0.53(0.07)$ B & $0.60(0.08) B$ & $0.23(0.03) \mathrm{C}$ & Gamma \\
\hline By-catch excluding large fauna & $4.59(0.48) \mathrm{A}$ & $1.11(0.11) \mathrm{A}$ & $0.44(0.04)$ B & $0.46(0.05) \mathrm{B}$ & Gamma \\
\hline Legal size ( $(\geq 95 \mathrm{~mm} \mathrm{SH})$ scallops & $1.03(0.19) \mathrm{A}$ & $0.97(0.09) \mathrm{A}$ & $1.12(0.11) \mathrm{A}$ & $1.03(0.10) \mathrm{A}$ & Normal (log-transformed) \\
\hline Undersize scallops ( $<95 \mathrm{~mm} \mathrm{SH})$ & $0.53(0.09) \mathrm{A}$ & $0.95(0.02) \mathrm{AB}$ & $0.85(0.02) B$ & $0.68(0.02) \mathrm{C}$ & $\begin{array}{l}\text { Normal (square-root } \\
\text { transformed) }\end{array}$ \\
\hline
\end{tabular}

$\mathrm{BRD}$, by-catch reduction device; SH, shell height; TED, turtle exclusion device.

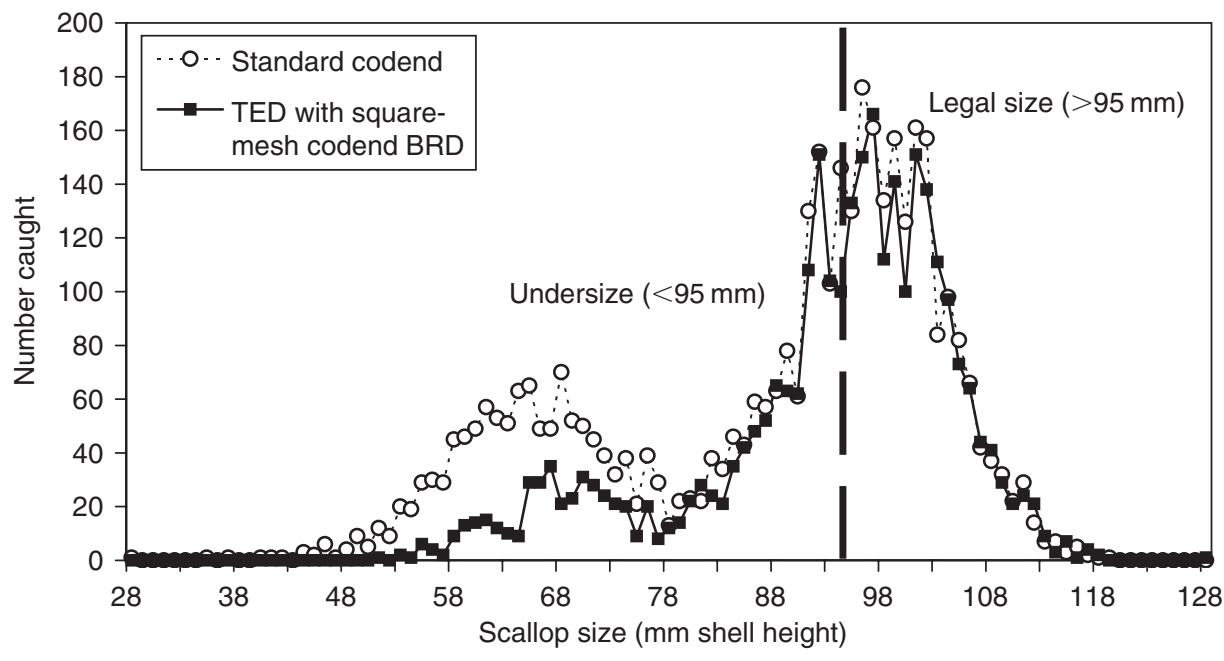

Fig. 3. Size-frequency distributions of saucer scallops Amusium balloti from the standard codend and the net with the turtle exclusion device (TED) and square-mesh codend.

scallops were small (i.e. $40-70 \mathrm{~mm} \mathrm{SH}$, Fig. 3), the relatively moderate reductions in catch weight equate to larger reductions in number. When numbers were examined, there were $39 \%$ fewer undersize scallops in the net with the TED and square-mesh codend compared with the standard codend (Fig. 3).

\section{Effects of codend type on Moreton Bay bugs}

Because there were relatively few bugs ( $T$. australiensis) caught in each net at each site, these data were best modelled as count data (i.e. number trawl ${ }^{-1}$ ) using a Poisson distribution and logarithm link function. Two analyses were undertaken, one for legal size bugs ( $\geq 75 \mathrm{~mm} \mathrm{CW}$ ) and one for undersize bugs. The observed mean catch rate of legal size bugs in the standard codend was 2.93 trawl $^{-1}$ (Table 3). Catch rates of legal size bugs differed significantly between codend types $(\mathrm{DR}=2.93$, d.f. $=3,174, P=0.032)$. When the TED and square-mesh codend were used together, the catch rate declined by $28 \%$ ( $\beta_{3}$ parameter estimate of 0.72 , Table 3$)$. The TED by itself reduced the catch rate by $21 \%\left(\beta_{3}\right.$ parameter estimate of 0.79 , Table 3$)$ and the square-mesh codend by itself reduced the catch rate by $20 \%$ ( $\beta_{3}$ parameter estimate of 0.80 , Table 3 ). Catch rates from all three codend types were significantly $(P<0.05$, Table 3$)$ lower than the standard codend according to $t$-tests of the model means.

The observed mean catch rate of undersize bugs from the standard codend was 1.02 trawl $^{-1}$ (Table 3). Catch rates of undersize bugs differed significantly between codend types $(\mathrm{DR}=14.60$, d.f. $=3,171, P<0.001)$. Although the TED significantly reduced the catch rate of undersize bugs by $18 \%\left(\beta_{3}\right.$ parameter estimate of 0.82 , Table 3 ), much larger reductions were achieved in square-mesh codend nets. The square-mesh codend by itself reduced the catch rate of undersize bugs by $74 \%\left(\beta_{3}\right.$ parameter estimate of 0.26 , Table 3 ) and when the TED and square-mesh codend were used together they reduced the catch rate by $76 \%$ ( $\beta_{3}$ parameter estimate of 0.24 , Table 3$)$. Catch rates from all three codend types were significantly ( $t$-test, $P<0.05$, Table 3) lower than the standard codend. 
Table 3. Effects of codend type on the catch rate of Moreton Bay bugs (Thenus australiensis) based on 236 measures (59 sites trawled $\times 4$ nets) Generalised linear modelling was used to quantify the effects. Significant differences between codends $(P<0.05)$ are bolded and identified by different letters (A, B or C). Parameter estimates were proportionally scaled so they could be compared with a standard net parameter value of 1 . Standard errors in parentheses

\begin{tabular}{|c|c|c|c|c|c|}
\hline \multirow[t]{2}{*}{ Catch component } & \multirow{2}{*}{$\begin{array}{c}\text { Mean observed catch } \\
\text { rate (number caught } \\
\text { trawl } 1^{-1} \text { ) in standard } \\
\text { net codend }\end{array}$} & \multicolumn{3}{|c|}{ Codend type parameter $\left(\beta_{3}\right)$ estimate } & \multirow[t]{2}{*}{ Distribution type } \\
\hline & & TED only & $\begin{array}{c}\text { Square-mesh } \\
\text { codend BRD only }\end{array}$ & $\begin{array}{l}\text { Square-mesh } \\
\text { codend and TED } \\
\text { together }\end{array}$ & \\
\hline Legal size bugs ( $\geq 75 \mathrm{~mm} \mathrm{CW})$ & $2.93(0.22) \mathrm{A}$ & $0.79(0.09) \mathrm{B}$ & $0.80(0.09) \mathrm{B}$ & $0.72(0.08) \mathrm{B}$ & Poisson \\
\hline Undersize bugs $(<75 \mathrm{~mm} \mathrm{CW})$ & $1.02(0.16) \mathrm{A}$ & $0.82(0.20) B$ & $0.26(0.08) \mathrm{C}$ & $0.24(0.08) \mathrm{C}$ & Poisson \\
\hline
\end{tabular}

$\mathrm{BRD}$, by-catch reduction device; $\mathrm{CW}$, carapace width; TED, turtle exclusion device.

\section{Effects of codend type on by-catch species}

Because most species were relatively uncommon (i.e. $90 \%$ of species were present in fewer than $14 \%$ of the 236 samples), resulting in high zero counts, quantifying the effects for the majority of species was problematic. Analyses were therefore undertaken on 49 taxonomic groups or species that comprised $\sim 90 \%$ of the weight of the by-catch in the standard codend. Statistically significant $(P<0.05)$ reductions were detected for 26 species (53\%) as a result of the TED, squaremesh codend or both (Table 4). The largest reduction in mean catch rate was $96 \%$ ( $\beta_{3}$ parameter estimate of 0.04 , Table 4$)$ for the longspine emperor ( $L$. genivittatus, $\mathrm{VR}=62.57$, d.f. $=$ $3,174, P<0.001)$. This reduction occurred in both nets with a square-mesh codend installed. Catch rates of the red portunid crab (P. rubromarginatus) differed significantly between codends $(\mathrm{VR}=55.93$, d.f. $=3,174, P<0.001)$ and were $88 \%$ lower in the net with TED and square-mesh codend $\left(\beta_{3}\right.$ parameter estimate of 0.12 , Table 4$)$. Other species with significantly large reductions due to the square-mesh codend included the threadfin bream $(N$. theodorei, $\mathrm{VR}=51.19$, d.f. $=$ 3, 174, $P<0.001$ ), dusky leatherjacket (Paramonacanthus otisensis, $\mathrm{VR}=39.26$, d.f. $=3,174, P<0.001)$, the Caledonian stinger (I. caledonicus, VR $=17.86$, d.f. $=3,174, P<0.001$ ), the toadfish (Torquigener pallimaculatus, $\mathrm{DR}=21.02$, d.f. $=3$, 229, $P<0.001$ ) and the paradise whiptail (Pentapodus paradiseus, $\mathrm{DR}=21.57$, d.f. $=3,171, P<0.001)$.

Catch rates of the elasmobranchs, the eastern shovelnose ray A. rostrata and the two stingrays D. kuhlii and Dasyatis leylandi, were best modelled using a binominal distribution with a logit link function. Aptychotrema rostrata was the largest of the by-catch species analysed (i.e. $554 \mathrm{~mm}$ mean TL in the standard codend) and the most commonly encountered elasmobranch. The probability of catching $A$. rostrata differed significantly between codend types (DR $=4.64$, d.f. $=3,171, P=0.003$ ) and was lowest in nets with the TED installed, although $t$-tests indicated no significant difference between the standard net and codends with TEDs (Table 4). No significant reductions were detected for D. kuhlii ( $\mathrm{DR}=0.21$, d.f. $=3,171, P=0.892)$ and $D$. leylandi $(\mathrm{DR}=0.63$, d.f. $=3,171, P=0.592)$, probably because of their relatively small size, which lowers the likelihood of the TED excluding them.

Obtaining meaningful length measurements for some species groups (i.e. seagrass $H$. spinulosa, algae $S$. racamosa and Lobophora sp. and bryozoans) was problematic and as a result the effects on length were limited to 39 taxa (Table 5). Length data were best modelled using a normal distribution with identity link function. There were no net position effects for any species and so this factor was dropped from the model. Significant differences between codend types were detected for 14 species (Table 5). Mean lengths increased significantly in nets with square-mesh codends for the prickly leatherjacket (Chaetodermis penicilligera, $\mathrm{VR}=8.85$, d.f. $=3,191, P<0.001$ ), Caledonian stinger (I. caledonicus, $\mathrm{VR}=6.88$, d.f. $=3,439, P<0.001$ ) and triggerfish (Abalistes stellaris, $\mathrm{VR}=9.32$, d.f. $=3,30$, $P<0.001$ ), suggesting that some smaller individuals of these species escaped through the square meshes (Table 5). The largest increase was for A. stellaris, which increased from a mean of $111.24 \mathrm{~mm} \mathrm{SL}$ in the standard net to $163.24 \mathrm{~mm} \mathrm{SL}$ in the net with both the TED and square-mesh codend. There were no significant effects on elasmobranch lengths. The effect of the TED was less marked. Of the 14 species in which a significant length effect was detected, $t$-tests on the model means indicated no significant difference $(P>0.05)$ between the standard codend and the codend with a TED only (Table 5 ).

\section{Variation in by-catch community structure}

MDS was carried out using all 236 sub-samples and the catch rates of 82 species that were present in $5 \%$ or more of the sub-samples. The resulting stress value was 0.17 for a threedimensional ordination. The ANOSIM routine revealed that bycatch assemblages differed significantly between depths (Global $r=0.240, P<0.001$ ), with the largest $R$ value (i.e. greatest difference) of 0.447 between the shallowest $(20 \mathrm{~m})$ and deepest $(50 \mathrm{~m})$ depth categories. The SIMPER routine showed that 50 species accounted for $90 \%$ of the dissimilarity between these two groups. Catch rates of unidentified sponges, blue swimmer crabs (P. pelagicus) and the longspine emperor (L. genivittatus) were much higher in the shallowest $(20 \mathrm{~m})$ category and together accounted for over $15 \%$ of the dissimilarity.

By-catch assemblages were also associated with latitude (Global $r=0.248, P<0.001$ ). The largest difference was between the $24.0^{\circ} \mathrm{S}$ and the $22.5^{\circ} \mathrm{S}$ groups $(r=0.668)$, where 43 species contributed $90 \%$ of the between-group dissimilarity. Species that contributed largely to the dissimilarity were unidentified sponges, which were much more abundant at lower latitudinal sites, and the portunid crabs (P. pelagicus and P. rubromarginatus) and prickly leatherjacket (C. penicilligera), which 


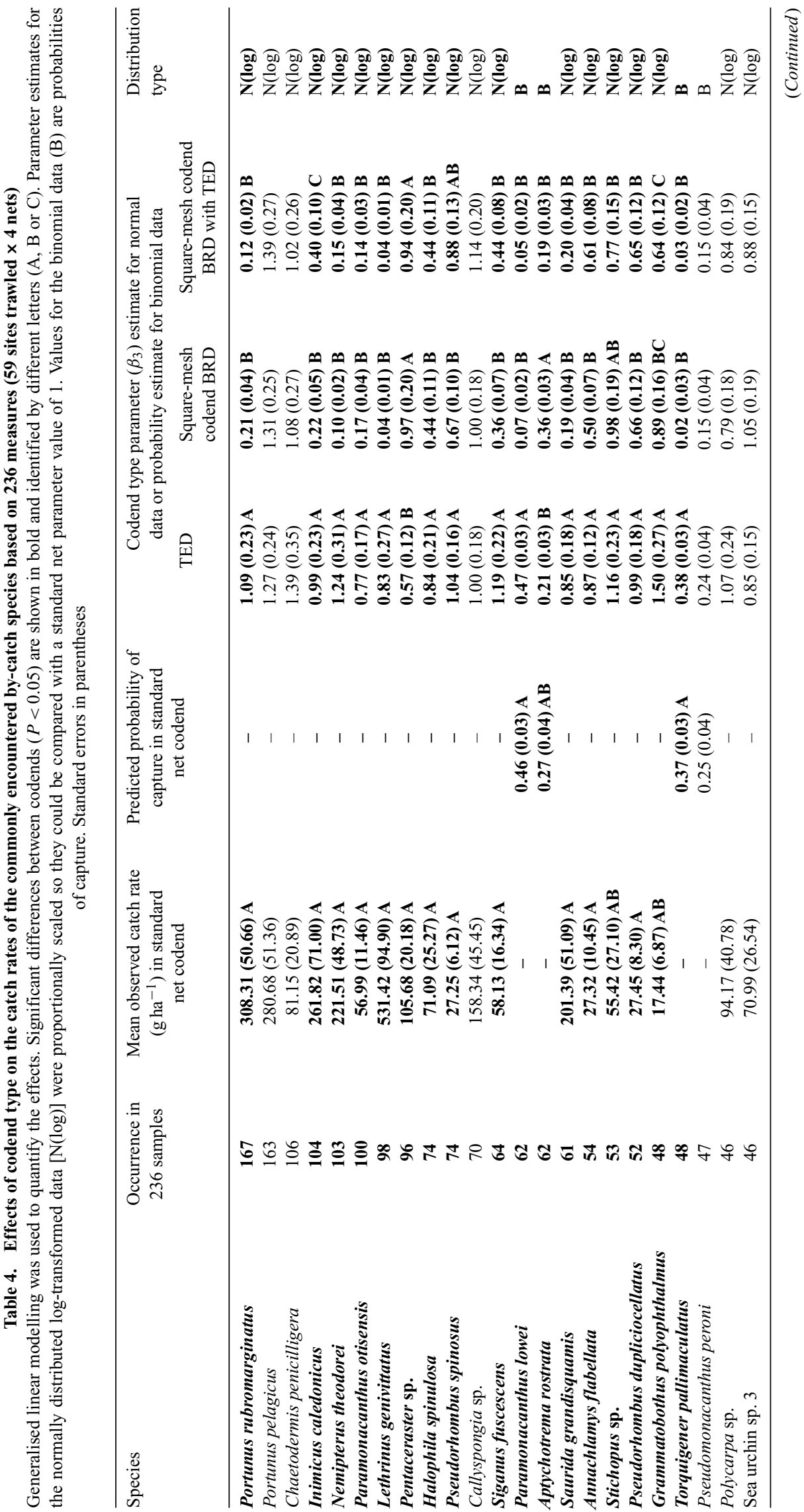




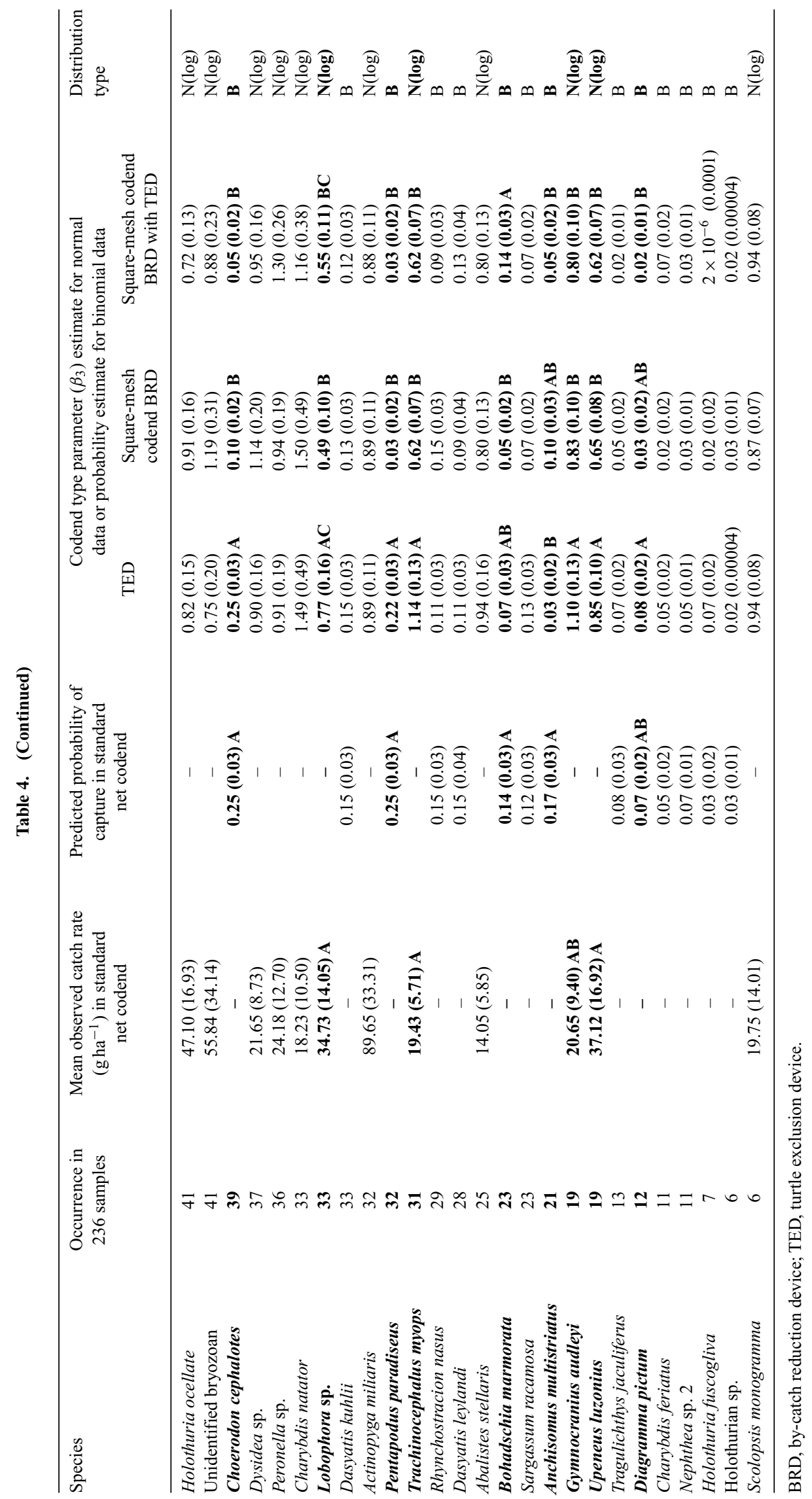


Table 5. Predicted mean length $(\mathrm{mm})$ of by-catch species from the four codend types based on 236 measures (59 sites trawled $\times 4$ nets) Generalised linear modelling (GLM) was used to estimate the means using a normal distribution with identity link function. Significant differences between codends $(P<0.05)$ are shown in bold and identified by different letters $(\mathrm{A}, \mathrm{B}$ or $\mathrm{C})$. Standard errors in parentheses

\begin{tabular}{|c|c|c|c|c|c|c|}
\hline \multirow[t]{2}{*}{ Species } & \multirow{2}{*}{$\begin{array}{l}\text { Occurrence in } \\
236 \text { samples }\end{array}$} & \multirow{2}{*}{$\begin{array}{c}\text { Number of } \\
\text { individuals } \\
\text { measured }\end{array}$} & \multicolumn{4}{|c|}{ Predicted mean length from GLM } \\
\hline & & & $\begin{array}{l}\text { Standard net } \\
\text { codend }\end{array}$ & TED only & $\begin{array}{c}\text { Square-mesh codend } \\
\text { BRD only }\end{array}$ & $\begin{array}{l}\text { Square-mesh codend } \\
\text { and TED together }\end{array}$ \\
\hline Portunus rubromarginatus & 167 & 1421 & $52.11(0.28) \mathrm{A}$ & $53.00(0.28)$ B & $54.00(0.50)$ B & $53.48(0.63)$ В \\
\hline Portunus pelagicus & 163 & 599 & $132.89(1.39)$ & $133.95(1.29)$ & $136.08(1.21)$ & $136.10(1.32)$ \\
\hline Chaetodermis penicilligera & 106 & 234 & $122.02(4.30) \mathrm{A}$ & $132.68(4.01) \mathrm{A}$ & $147.95(5.32) \mathrm{B}$ & $153.08(4.86) B$ \\
\hline Inimicus caledonicus & 104 & 483 & $127.76(2.13) \mathrm{A}$ & $127.63(2.14) \mathrm{A}$ & $144.84(5.44)$ B & $143.90(3.96) \mathrm{B}$ \\
\hline Nemipterus theodorei & 103 & 598 & $157.47(1.31) \mathrm{A}$ & $152.07(1.00) \mathrm{B}$ & $156.03(5.08) \mathrm{AB}$ & $162.59(2.74) \mathrm{A}$ \\
\hline Paramonacanthus otisensis & 100 & 459 & $89.61(0.94)$ & $87.22(1.09)$ & $86.39(3.18)$ & $88.10(3.86)$ \\
\hline Lethrinus genivittatus & 98 & 864 & $137.81(1.39) \mathrm{A}$ & $127.75(1.49) \mathrm{B}$ & $124.70(5.55) \mathrm{B}$ & $154.67(5.76) \mathrm{C}$ \\
\hline Pentaceraster sp. & 96 & 299 & $144.37(4.48)$ & $143.55(4.84)$ & $154.92(3.49)$ & $154.02(3.40)$ \\
\hline Pseudorhombus spinosus & 74 & 150 & $198.72(4.59)$ & $192.24(4.11)$ & $197.85(6.86)$ & $206.79(5.90)$ \\
\hline Siganus fuscescens & 64 & 227 & $122.12(2.14) \mathrm{A}$ & $117.69(2.04) \mathrm{A}$ & $113.93(8.05) \mathrm{A}$ & $140.39(6.42) \mathrm{B}$ \\
\hline Paramonacanthus lowei & 62 & 266 & $103.01(1.88) \mathrm{A}$ & $100.82(1.51) \mathrm{A}$ & $127.11(9.54)$ B & 103.95 (7.61) AB \\
\hline Aptychotrema rostrata & 63 & 107 & $554.50(23.80)$ & $539.20(35.10)$ & $583.10(20.90)$ & $576.30(31.50)$ \\
\hline Saurida grandisquamis & 61 & 138 & $306.37(7.78)$ & $294.33(6.95)$ & * & $284.91(56.61)$ \\
\hline Annachlamys flabellata & 54 & 156 & $54.42(0.57) \mathrm{A}$ & $57.08(0.64)$ B & $55.96(0.92) \mathrm{AB}$ & $56.85(0.84)$ B \\
\hline Stichopus sp. & 53 & $44 * *$ & $250.20(30.20)$ & $217.80(26.70)$ & $238.60(34.10)$ & $247.90(41.80)$ \\
\hline Pseudorhombus dupliciocellatus & 52 & 123 & $191.35(7.08)$ & $190.81(6.19)$ & $209.14(13.15)$ & $193.50(15.64)$ \\
\hline Grammatobothus polyophthalmus & 48 & 101 & $174.91(4.81)$ & $161.31(3.21)$ & $162.66(6.59)$ & $161.64(10.48)$ \\
\hline Torquigener pallimaculatus & 48 & 126 & $93.61(2.85) \mathrm{A}$ & $90.42(2.05) \mathrm{A}$ & $52.47(17.55)$ B & $93.61(2.85) \mathrm{A}$ \\
\hline Pseudomonacanthus peroni & 47 & 80 & $196.37(7.39)$ & $206.10(8.45)$ & $212.87(12.48)$ & 208.34 (10.59) \\
\hline Sea urchin sp. 3 & 46 & 172 & $69.52(2.39)$ & $67.33(2.00)$ & $68.15(2.16)$ & $69.17(2.69)$ \\
\hline Holothuria ocellata & 41 & 64 & $175.41(6.17) \mathrm{AB}$ & $162.67(10.12) \mathrm{A}$ & $192.04(8.40) B$ & $155.96(11.31) \mathrm{AC}$ \\
\hline Choerodon cephalotes & 39 & 80 & $156.58(7.04)$ & $166.78(7.78)$ & $171.65(15.50)$ & $193.87(25.31)$ \\
\hline Peronella sp. & 36 & 60 & $122.39(5.61)$ & $114.40(6.85)$ & $131.23(7.63)$ & $120.56(3.45)$ \\
\hline Charybdis natator & 33 & 35 & $91.22(12.45)$ & $86.80(8.59)$ & $86.43(7.08)$ & $113.25(13.86)$ \\
\hline Dasyatis kuhlii & 33 & 48 & $278.10(17.30)$ & $286.10(14.70)$ & $273.00(15.50)$ & $270.00(20.10)$ \\
\hline Actinopyga miliaris & 32 & 46 & $185.69(8.38) \mathrm{A}$ & $195.88(7.88) \mathrm{A}$ & $155.60(8.41) \mathrm{B}$ & 192.13 (7.17) A \\
\hline Pentapodus paradiseus & 32 & 66 & $156.57(3.79)$ & $157.75(5.40)$ & $144.57(12.95)$ & $124.74(17.59)$ \\
\hline Trachinocephalus myops & 31 & 54 & $172.44(7.84)$ & $189.24(5.25)$ & $*$ & $*$ \\
\hline Rhynchostracion nasus & 29 & 38 & $130.70(13.00) \mathrm{A}$ & $128.50(14.40) \mathrm{A}$ & $211.20(12.20) B$ & $155.70(32.70) \mathrm{A}$ \\
\hline Dasyatis leylandi & 28 & 48 & $192.50(26.30)$ & * & $172.70(53.50)$ & $169.40(62.40)$ \\
\hline Abalistes stellaris & 25 & 50 & $111.24(5.84) \mathrm{A}$ & $107.31(5.46) \mathrm{A}$ & $155.35(13.65)$ B & $163.24(10.66)$ B \\
\hline Bohadschia marmorata & 23 & 31 & $180.10(15.40)$ & $157.30(37.80)$ & $180.10(35.20)$ & $197.60(14.20)$ \\
\hline Anchisomus multistriatus & 21 & 24 & $312.29(6.32)$ & $332.29(20.16)$ & $342.29(9.07)$ & $312.29(6.32)$ \\
\hline Gymnocranius audleyi & 19 & 87 & $129.92(5.29) \mathrm{A}$ & $112.50(3.75) \mathrm{B}$ & $150.97(13.52) \mathrm{A}$ & 151.74 (11.96) AC \\
\hline Upeneus luzonius & 19 & 48 & $145.44(3.54)$ & $142.98(4.42)$ & $139.78(12.65)$ & $130.00(18.30)$ \\
\hline Tragulichthys jaculiferus & 13 & 13 & $127.50(53.70)$ & $170.00(58.60)$ & $155.00(62.10)$ & $127.50(53.70)$ \\
\hline Diagramma pictum & 12 & 21 & $180.30(24.60)$ & $182.40(21.30)$ & $180.30(24.60)$ & $241.50(62.20)$ \\
\hline Charybdis feriatus & 11 & 12 & $132.50(5.27)$ & $164.50(8.82)$ & $132.50(5.27)$ & $124.50(6.67)$ \\
\hline Scolopsis monogramma & 6 & 9 & $220.24(8.32)$ & $220.24(8.32)$ & * & $189.52(12.84)$ \\
\hline
\end{tabular}

BRD, by-catch reduction device; TED, turtle exclusion device.

*Too few individuals sampled to predict mean length.

**Crushed and incomplete individuals reduced the number of length measures that could be obtained.

were more abundant at higher latitudes. These four taxa contributed over $20 \%$ of the dissimilarity between groups. Other significant differences were detected between the $24.0^{\circ} \mathrm{S}$ group and the $22.5^{\circ} \mathrm{S}$ group $(r=0.566)$, the $24.0^{\circ} \mathrm{S}$ group and the $23.5^{\circ} \mathrm{S}$ group $(r=0.525)$, and the $25.0^{\circ} \mathrm{S}$ group and the $22.5^{\circ} \mathrm{S}$ group $(r=0.509)$.

The MDS plot (Fig. 4) indicated that by-catch assemblages were also affected by codend type; samples from nets with square-mesh codends generally clustered in the upper half of the graph, whereas those from nets without square-mesh codends clustered on the lower half. ANOSIM confirmed that by-catch assemblages differed significantly between codend types (Global $r=0.181, P<0.001$ ). The largest difference was between the TED and the square-mesh codend $(r=0.334$, Table 6) where 55 taxa contributed $90 \%$ of the dissimilarity. Results from the SIMPER routine showed that species that contributed most to the dissimilarity between these groups were (1) unidentified sponges and the eastern shovelnose ray (A. rostrata), which were largely excluded by the TED, and (2) the threadfin bream ( $N$. theodorei), longspine emperor (L. genivittatus), lizard fish (S. grandisquamis), red portunid crab (P. rubromarginatus), longfin waspfish (Apistus carinatus), painted lizard 


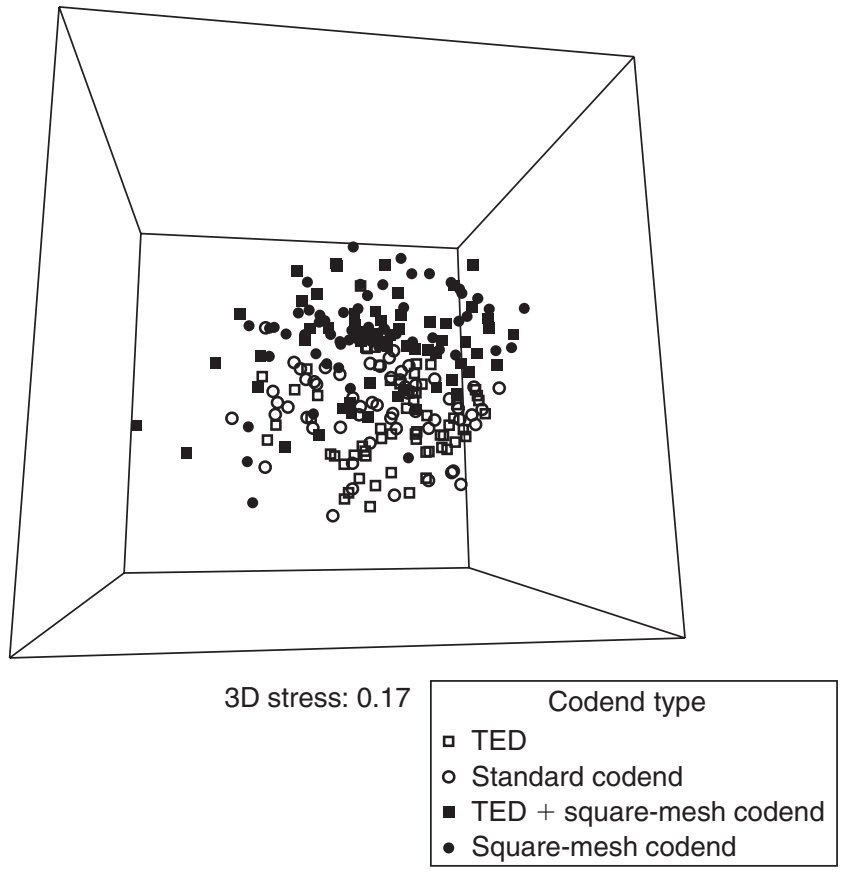

Fig. 4. Multi-dimensional scaling (MDS) of 82 species from 236 ( 59 sites $\times 4$ nets) by-catch sub-samples from the Queensland scallop fishery showing the effect of codend type on the structure of by-catch assemblages. Sub-samples from nets with square-mesh codends (i.e. solid black circles and solid black squares) are largely distributed in the upper half of the plot, whereas those without square-mesh codends (i.e. open circles and open squares) mostly occur in the lower half.

Table 6. $R$ statistic values and significance levels for differences in by-catch community structure between codend types

\begin{tabular}{lcc}
\hline Groups & $R$ statistic & $\begin{array}{c}\text { Significance } \\
\text { level }\end{array}$ \\
\hline TED, standard net & 0.033 & 0.018 \\
TED, TED and square-mesh codend & 0.235 & 0.001 \\
TED, square-mesh codend & 0.334 & 0.001 \\
Standard net, TED and square-mesh codend & 0.212 & 0.001 \\
Standard net, square-mesh codend & 0.225 & 0.001 \\
TED and square-mesh codend, & 0.047 & 0.002 \\
square-mesh codend & & \\
\hline
\end{tabular}

TED, turtle exclusion device.

fish (Trachinocephalus myops) and the mud flathead (Ambiserrula jugosa), which were largely excluded by the square-mesh codend. Collectively, these species accounted for $\sim 25 \%$ of the dissimilarity between the two codend types. The results suggest that the square-mesh codend effectively removes much of the by-catch, almost completely removing several species, and is therefore responsible for most of the dissimilarity between the TED and square-mesh codend groups.

\section{Discussion}

Results from the charter demonstrated that when the TED and square-mesh codend were installed together, the mean total by-catch rate was reduced by $77 \%$ with no reduction in the catch rate of legal size scallops, compared with a standard diamondmesh codend (Table 2). Significant reductions in the catch rates of undersize scallops (Table 2), legal size Moreton Bay bugs and undersize bugs (Table 3 ) also occurred when the TED and square-mesh codend were installed together. The reduction in by-catch rate is a positive step towards reducing the fishery's ecological impacts, but it also reflects the poor selectivity of nets that have traditionally been used in benthic trawl fisheries (Pascoe 1997; Broadhurst et al. 2006b).

Several studies have compared diamond-mesh and squaremesh codends in commercial fisheries in the Mediterranean (Bahamon et al. 2006; Ordines et al. 2006; Sarda et al. 2006), the Aegean Sea (Stergiou et al. 1997), the North Sea (Catchpole et al. 2006), Iceland (Thorsteinsson 1992), the northern Baltic Sea (Suuronen and Millar 1992), the Belgian coast (Fonteyne and M'Rabet 1992) and eastern Australia (Broadhurst et al. 2004, 2006a; Macbeth et al. 2007). Most of these studies focussed on comparing the size selectivities of the two mesh types on target species or species of commercial value and demonstrated significant improvements in selectivity with square-mesh codends. In the Mediterranean bottom trawl fisheries, which catch and market over 60 species of fish, cephalopods and crustaceans (Ordines et al. 2006), square-mesh codends are used primarily to reduce incidental catches of small or suboptimal size commercial species. The Queensland scallop fishery is essentially a single-species fishery, although Moreton Bay bugs are a commercially important component of the catch. By-catch greatly exceeds the targeted scallop catch and is composed of at least 382 taxa - characteristics that are typical of tropical-subtropical benthic trawl fisheries (Alverson et al. 1994; Stobutzki et al. 2001; Kelleher 2005). The objectives of the present study differed from most of the abovementioned studies by evaluating a square-mesh codend primarily as device for reducing incidental catches of the numerous non-commercial species. The results suggest that square-mesh codends have high potential as a BRD in the Queensland scallop fishery - mean total by-catch rate was reduced by $40 \%$ in the net with the square-mesh codend by itself (Table 2) with significant reductions for the majority of species analysed (Table 4), mainly due to the square-mesh codend. Although it was not an objective of the study, a significant improvement in size selectivity of the targeted scallop catch was demonstrated, mainly due to the square-mesh codend (Table 2, Fig. 3).

The $77 \%$ reduction in mean total by-catch rate is large compared with other trawl fishery BRDs, which typically range between 30 and $70 \%$ (Broadhurst et al. 2006b), and was achieved because the two devices excluded different components of the by-catch. When used together, they complemented each other resulting in the exclusion of the great majority of the by-catch. The TED excluded much of the large by-catch fauna, which made up $64 \%$ of the total by-catch weight and was dominated by large sponges. Codends with TEDs also resulted in the lowest catch rates of eastern shovelnose ray ( $A$. rostrata), which was the largest and most common of the elasmobranchs analysed, although these reductions did not differ significantly from the standard codend (Table 4). Brewer et al. (2006) also reported significant reductions in the catch rates of large fauna, including turtles, sharks, rays and sponges, due to the TEDs used by fishers 
in Australia's northern prawn fishery. The square-mesh codend by itself was highly effective and reduced the mean catch rate of small by-catch by $56 \%$ (i.e. by-catch excluding large fauna; $\beta_{3}$ parameter estimate of 0.44 , Table 2 ). When used together, the reductions from both devices were largely additive.

The improved size selectivity of the scallop catch (Fig. 3) will help promote adoption of square-mesh codends by fishers, specifically because there was (1) no reduction in legal size ( $\geq 95 \mathrm{~mm} \mathrm{SH}$ ) scallop catch rate and (2) a significant reduction in undersize $(<95 \mathrm{~mm} \mathrm{SH})$ scallop catch rate (Table 2$)$. As mentioned above, several studies have demonstrated improvements in selectivity by square-mesh codends compared with diamond-mesh codends. Bahamon et al. (2006), for example, showed substantial improvement in the size selectivity of commercially important European hake (Murluccius merluccius), poor cod (Trisopterus minutus) and greater forkbeard (Phycis blennoides) in the Mediterranean demersal trawl fishery by switching from $40-\mathrm{mm}$ diamond-mesh codends to $40-\mathrm{mm}$ square-mesh codends. Catchpole et al. (2006) undertook a similar study to ours, comparing a standard diamond-mesh codend, standard diamond-mesh codend with Swedish grid, square-mesh codend, and square-mesh codend with Swedish grid, in the English lobster (Nephrops norvegicus) trawl fishery to reduce incidental catches of cod (Gadus morhua), which was considered to be overfished. Although they were able to greatly reduce the number of cod caught, they also incurred a $50 \%$ reduction in catch and value of lobsters, which was economically unacceptable to fishers.

The incidental fishing mortality of undersize scallops in the fishery is unknown but may be considerable to the point of lowering the maximum sustainable yield. In the Bass Strait scallop (Pectin fumatus) fishery, McLoughlin et al. (1991) found the mortality rate of scallops that had been returned to the sea after dredging to be highly elevated, whereas Bremec et al. (2004) found no evidence that exposure to air or the on-board grading process affected scallop survival rates in the Patagonian scallop (Zygochlamys patagonica) trawl fishery. Dredge (1988) undertook a tagging experiment on $A$. balloti in the Queensland fishery to examine the effects of trawling on scallop survival rates. He detected a marginal effect, with small size classes (i.e. $<45$ to $65 \mathrm{~mm} \mathrm{SH}$ ) likely to experience higher trawl mortality than larger sizes (i.e. $>65 \mathrm{~mm} \mathrm{SH}$ ). The sources of incidental fishing mortality on undersize scallops in the fishery are additive and likely to result from (1) impact with the otter boards and ground chains, (2) crushing in the codend, (3) damage while escaping through trawl mesh, (4) impact from being dropped onto the sorting tray from the codend, (5) rigorous movement and chipping during grading, (6) exposure to air and (7) predation when returned to the sea. Incidental capture may also predispose individuals and the population to disease, as suggested by McLoughlin et al. (1991). Observations on commercial vessels and results from the present study indicate that catches of undersize scallops are frequently high (i.e. $0.53 \mathrm{~kg}$ undersize scallops for every $1.03 \mathrm{~kg}$ of legal size in the standard net, Table 2) and therefore any technology that reduces their incidental capture and mortality is likely to be highly desirable. Although some undersize scallops would still be retained (Fig. 3), total incidental fishing mortality on these small size classes would likely decline if square-mesh codends were adopted by the fleet.
Similarly, the $76 \%$ reduction in mean catch rate of undersize bugs (T. australiensis, Table 3 ) suggests that the incidental fishing mortality on this species would also decline if squaremesh codends were adopted. Wassenberg and Hill (1993) found the survival of scyllarid lobsters (Scyllarus demani and Thenus orientalis - now Thenus parindicus after the review by Burton and Davie 2007) held for 7 days after trawling was high (i.e. $\geq 98 \%$ ). However, the duration of the trawls used by Wassenberg and Hill was shorter (i.e. $60 \mathrm{~min}$ ) than the average trawl in the scallop fishery (i.e. $155 \mathrm{~min}$, Robins 1995), and therefore their survival rate estimate may be too high for the scallop fishery. A tag-release study of $T$. australiensis and T. parindicus showed that their recapture rates, and by inference their survival rates, declined with initial trawl duration and the duration they were onboard before release (Courtney et al. 2001). Any management measure that reduces the incidental capture of undersize bugs is likely to have a positive effect on the stock and to be viewed favourably by both fishers and the fishery managers.

The reduction in catch rate of legal size bugs (Table 3) was significant and attributed to both the TED and square-mesh codend. Some of the loss was likely due to the TED excluding large amounts of sponges. Before they are expelled, large sponges accumulate in front of the TED. It seems likely that this build-up of sponges blocks the bugs from passing into the codend and provides a surface they can cling to. When the mass of sponge accumulates enough, it is expelled through the TED escape opening, taking the bugs with it. This loss of legal size bugs might be addressed by altering the angle of the TED so that it expels sponges more quickly, preventing them from building up.

\section{Variation in by-catch community structure}

By-catch from the fishery was highly diverse (i.e. 382 taxa), largely comprised of sponges (i.e. $\sim 60 \%$ of total by-catch weight), portunid crabs, small demersal and benthic fish (e.g. leatherjackets, stingerfish, bearded ghouls, nemipterids, longspine emperors, lizard fish, triggerfish, flounders and rabbitfish), elasmobranchs (i.e. mainly rays) and invertebrates (i.e. sea stars, sea urchins, sea cucumbers and bivalve molluscs) and varied significantly with depth, latitude and codend type. The high diversity reflects the tropical-subtropical distribution (i.e. $23-25^{\circ} \mathrm{S}$ ) of the fishery. Laurenson et al. (1993) recorded 150 species of teleosts, elasmobranchs and invertebrates in the bycatch of a similar trawl fishery for $A$. balloti in south-western Australia $\left(31-34^{\circ} \mathrm{S}\right)$.

Watson et al. (1990) examined variation in the benthic faunal communities associated with a central Queensland $\left(18-19^{\circ} \mathrm{S}\right)$ prawn trawl fishery. Faunal composition was affected more by location of sample sites than by time (i.e. month). They also differentiated the communities into nearshore, midshelf and inter-reef groups and found weakly separated wet-and-dry season temporal groupings. On the Argentinian continental shelf, macrobenthic by-catch assemblages in the Patogonian scallop trawl fishery $\left(38-47^{\circ} \mathrm{S}\right)$ were strongly affected by latitude and the oceanographic conditions created by a shelfbreak front (i.e. strong variations in water temperature, density and salinity causing intense advection), which affects the ecosystem's trophic dynamics (Bremec and Lasta 2002). 


\section{Extrapolating the results to the scallop fishery}

When results from the charter are extrapolated to the scallop fleet, based on logbook catch data, they suggest that there is potential to reduce by-catch in the scallop fishery by several thousand tonnes annually if the fleet adopted the combination of TED and square-mesh codend, with no loss of the targeted legal size scallop catch. For example, scallop landings for the period 1988 to 1999 averaged 1100 tonnes of meat annually (Williams 2002), which equates to $\sim 5500$ tonnes of unshucked scallops annually. Measurements obtained by researchers aboard Queensland scallop vessels indicate that $\sim 2.5 \mathrm{~kg}$ of by-catch was caught for every $1 \mathrm{~kg}$ of unshucked legal size scallops before the implementation of TEDs and BRDs - a ratio of $2.5: 1$. This ratio is significantly lower than catch rates from the standard diamondmesh net obtained during the charter (Table $2 ; 15.89 \mathrm{~kg}$ of total by-catch for $1.03 \mathrm{~kg}$ of legal size scallops). By assuming the $2.5: 1$ ratio, estimates of the scallop meat weight from logbook data from 1988 to 1999 , and simple extrapolation, we estimate that $\sim 13750$ tonnes of by-catch was produced by the scallop fishery annually over the period. If all of the scallop trawlers used the TED and square-mesh codend that were trialled herein, and the $77 \%$ reduction was extrapolated to the scallop fleet, it would equate to a reduction in by-catch of $\sim 10588$ tonnes to 3163 tonnes annually, with no loss of the legal size scallop catch. These estimates are provided to give a general understanding of the magnitude of by-catch production in the scallop fishery and the potential reduction that could be achieved. They do not include by-catch due to undersize scallops and should not be used as an absolute estimate of by-catch production in the fishery in the past, or as a reference for the future.

Although the Queensland scallop fishery was first fished in the mid 1950s (Ruello 1975), impacts from the fishery on benthic habitats and communities remain poorly understood. Results from the present study could be used as baseline data and to develop a stratified by-catch monitoring program capable of detecting change in by-catch species' abundances and benthic community structure. Monitoring programs need to consider how changes in fishing gears used by both the fleet and monitoring vessels could affect the population sizes for both by-catch and target species, and interpretation of their catch rates, otherwise incorrect conclusions may be drawn. For example, in Australia's northern prawn fishery, Griffiths et al. (2006) found that the mean length of some elasmobranch species in the fishery's bycatch declined after the introduction of TEDs and that this could falsely indicate that the impact of fishing had increased, leading to the incorrect conclusion that sustainability of these species had declined. In the present study, the catch rates and mean lengths of several by-catch species, and the by-catch faunal assemblages, changed markedly as a result of codend type. If square-mesh codends are adopted by the fleet, then any proposed monitoring program should consider how this could affect interpretation of monitoring results.

\section{Acknowledgements}

This research was funded by the Australian Government Fisheries Research and Development Corporation (FRDC Project No. 2000/170) and the Queensland Department of Primary Industries and Fisheries. Dr Matt
Broadhurst of the New South Wales Department of Primary Industries kindly provided advice on the application and construction of square-mesh codends. We gratefully acknowledge the skills and seamanship provided by Colin, Wayne and Darren Flaherty and for making their vessel FV Southern Intruder available for the charter. Brad May assisted with processing the by-catch. The research charter and by-catch sampling carried out in the Great Barrier Reef Marine Park were undertaken under permit approval number G01/437. Two anonymous referees provide useful comments on an earlier draft of this paper.

\section{References}

Alverson, D. L., Freeberg, M. H., Pope, J. G., and Murawski, S. A. (1994). A global assessment of fisheries bycatch and discards. FAO Fisheries Technical Paper 330. (FAO, Rome.)

Andrew, N. L., and Pepperell, J. G. (1992). The by-catch of shrimp trawl fisheries. Oceanography and Marine Biology: An Annual Review 30, 527-565.

Bahamon, N., Sarda, F., and Suuronen, P. (2006). Improvement of trawl selectivity in the NW Mediterranean demersal fishery by using a $40 \mathrm{~mm}$ square mesh codend. Fisheries Research 81, 15-25. doi:10.1016/ J.FISHRES.2006.05.020

Barker, J., O’Sullivan, S., Jebreen, E., Roy, D., and Kennedy, C. (2004). Fisheries long-term monitoring program. Benthic marine fauna composition in the Queensland scallop fishery area in 2000 and 2002. Department of Primary Industries and Fisheries, Queensland. Information Series QI04096.

Bremec, C. S., and Lasta, M. L. (2002). Epibenthic assemblage associated with scallop (Zygochlamys patagonica) beds in the Argentinian shelf. Bulletin of Marine Science 70, 89-105.

Bremec, C. S., Lasta, M. L., and Hernandez, D. (2004). Survival of Patagonian scallop (Zygochlamys patagonica, King and Broderip, 1832) after the size selection process on commercial fishing vessels. Fisheries Research 66, 49-52. doi:10.1016/S0165-7836(03)00179-6

Brewer, D., Rawlinson, N., Eayrs, S., and Burridge, C. Y. (1998). An assessment of bycatch reduction devices in a tropical Australian prawn trawl fishery. Fisheries Research 36, 195-215. doi:10.1016/S01657836(98)00096-4

Brewer, D., Heales, D., Milton, D., Dell, Q., Fry, G., Venables, B., and Jones, P. (2006). The impact of turtle excluder devices and bycatch reduction devices on diverse tropical marine communities in Australia's northern prawn trawl fishery. Fisheries Research 81, 176-188. doi:10.1016/J.FISHRES.2006.07.009

Broadhurst, M. K. (2000). Modifications to reduce bycatch in prawn trawls: a review and framework for development. Reviews in Fish Biology and Fisheries 10, 27-60. doi:10.1023/A:1008936820089

Broadhurst, M. K., Larsen, R. B., Kennelly, S. J., and McShane, P. E. (1999). Use and success of composite square-mesh codends in reducing bycatch and in improving size-selectivity of prawns in Gulf St. Vincent, South Australia. Fishery Bulletin 97, 434-448.

Broadhurst, M. K., Millar, R. B., Kennelly, S. J., Macbeth, W. G., Young, D. J., and Gray, C. A. (2004). Selectivity of conventional diamond- and novel square-mesh codends in an Australian estuarine penaeid-trawl fishery. Fisheries Research 67, 183-194. doi:10.1016/J.FISHRES.2003.09.043

Broadhurst, M. K., Millar, R. B., Wooden, M. E. L., and Macbeth, W. G. (2006a). Optimising codend configuration in a multispecies demersal trawl fishery. Fisheries Management and Ecology 13, 81-92. doi:10.1111/J.1365-2400.2006.00479.X

Broadhurst, M. K., Suuronen, P., and Hulme, A. (2006b). Estimating collateral mortality from towed fishing gear. Fish and Fisheries 7, 180-218.

Burton, T. E., and Davie, P. J. F. (2007). A revision of the shovel-nosed lobsters of the genus Thenus (Crustacea: Decapoda: Scyllaridae), with descriptions of three new species. Zootaxa 1429, 1-38. 
Catchpole, T. L., Revill, A. S., and Dunlin, G. (2006). An assessment of the Swedish grid and square-mesh codend in the English (Farn Deeps) Nephrops fishery. Fisheries Research 81, 118-125. doi:10.1016/ J.FISHRES.2006.08.004

Clarke, K. R., and Warwick, R. M. (1994). 'Change in Marine Communities: An Approach to Statistical Analysis and Interpretation.' (Plymouth Marine Laboratories: Plymouth.)

Courtney, A. J., Cosgrove, M. G., and Die, D. J. (2001). Population dynamics of scyllarid lobsters of the genus Thenus spp. on the Queensland (Australia) east coast I. Assessing the effects of tagging. Fisheries Research 53, 251-261. doi:10.1016/S0165-7836(00)00274-5

Courtney, A. J., Tonks, M. L., Campbell, M. J., Roy, D. P., Gaddes, S. W., Kyne, P. M., and O'Neill, M. F. (2006). Quantifying the effects of bycatch reduction devices in Queensland's (Australia) shallow water eastern king prawn (Penaeus plebejus) trawl fishery. Fisheries Research 80, 136-147. doi:10.1016/J.FISHRES.2006.05.005

Currie, D. R., and Parry, G. D. (1994). The impact of scallop dredging on a soft sediment community using multivariate techniques. Memoirs of the Queensland Museum 36, 315-326.

Dichmont, C. M., Dredge, M. C. L., and Yeomans, K. (2000). The first large-scale fishery-independent survey of the saucer scallop, Amusium japonicum balloti in Queensland, Australia. Journal of Shellfish Research 19, 731-739.

Dredge, M. (1988). Trawl-induced mortality of juvenile saucer scallops, Amusium japonicum balloti Bernardi, measured from video recordings and tag recoveries. In 'Proceedings of the Australasian Scallop Workshop, Taroona, Tasmania, July 1988’. (Eds M. C. L. Dredge, W. F. Zacharin and L. M. Joll.) pp. 103-110.

Dredge, M. C. L. (1994). Modelling management measures in the Queensland scallop fishery. Memoirs of the Queensland Museum 36, 277-282.

DuPaul, W. D., Brust, J. C., and Kirkley, J. E. (1996). Bycatch in the United States and Canadian sea scallop fisheries. In 'Solving Bycatch Workshop: Considerations for Today and Tomorrow, Fairbanks, AK'. (Ed. T. Wray.) pp. 175-182. University of Alaska Sea Grant College Program Report 96-03.

Eayrs, S., Buxton, C., and McDonald, B. (1997). 'A Guide to Bycatch Reduction in Australian Prawn Trawl Fisheries.' (Australian Maritime College: Launceston.)

FAO (1996). Technical consultation on reduction of wastage in fisheries. FAO Fisheries Report No. 547. (FAO, Rome.)

Fonteyne, R., and M'Rabet, R. (1992). Selectivity experiments on sole with diamond and square mesh codends in the Belgian coastal beam traw fishery. Fisheries Research 13, 221-233. doi:10.1016/0165-7836(92) 90078-8

GenStat (2007). GenStat (PC/Windows XP), 9th edn. Lawes Agricultural Trust. (Rothamsted Experimental Station: Harpenden, UK.)

Griffiths, S. P., Brewer, D. T., Heales, D. S., Milton, D. A., and Stobutzki, I. C. (2006). Validating ecological risk assessments for fisheries: assessing the impacts of turtle excluder devices on elasmobranch bycatch populations in an Australian trawl fishery. Marine and Freshwater Research 57, 395 401. doi:10.1071/MF05190

Hall, S. J., and Mainprize, B. M. (2005). Managing by-catch and discards: how much progress are we making and how can we do better? Fish and Fisheries 6, 134-155. doi:10.1111/J.1467-2979.2005.00183.X

Hall, M., Alverson, D. L., and Metuzals, K. (2000). By-catch: problems and solutions. Marine Pollution Bulletin 41, 204-219. doi:10.1016/S0025326X(00)00111-9

Jones, C. M., and Derbyshire, K. (1988). Sampling the demersal fauna from a commercial penaeid prawn fishery off the central Queensland coast. Memoirs of the Queensland Museum 25, 403-415.

Kelleher, K. (2005). Discards in the world's marine fisheries. An update FAO Fisheries Technical Paper 470, 131

Kerrigan, B., Gaddes, S., and Norris, W. (2004). Review of the sustainability of fishing effort in the Queensland East Coast Trawl Fishery. The State of Queensland, Department of Primary Industries and Fisheries, Report QI04067.

Laurenson, L. J. B., Unsworth, P., Penn, J. W., and Lenanton, R. C. J. (1993). The impact of trawling for saucer scallops and western king prawns on the benthic communities in coastal waters off south Western Australia. Fisheries Department of Western Australia, Fisheries Research Report 100.

Macbeth, W. G., Broadhurst, M. K., Millar, R. B., and Smith, D. A. (2005). Increasing codend mesh openings: an appropriate strategy for improving the selectivity of penaeid fishing gears in an Australian estuary? Marine and Freshwater Research 56, 889-900. doi:10.1071/MF04256

Macbeth, W. G., Millar, R. B., Broadhurst, M. K., Hewitt, C., and Wooden, M. E. L. (2007). Intra-fleet variability in the size selectivity of squaremesh trawl codend for school prawns (Metapenaeus macleayi). Fisheries Research 86, 92-98. doi:10.1016/J.FISHRES.2007.05.003

McLoughlin, R. J., Young, P. C., and Parslow, J. (1991). The Australian scallop dredge: estimates of catching efficiency and associated indirect fishing mortality. Fisheries Research 11, 1-24. doi:10.1016/01657836(91)90030-J

Montgomery, D. C. (1997). 'Design and Analysis of Experiments.' 4th edn. (John Wiley and Sons: Brisbane.)

O’Neill, M. F., Courtney, A. J., Good, N. M., Turnbull, C. T., Yeomans, K. M., Staunton Smith, J., and Shootingstar, C. (2005). Reference point management and the role of catch-per-unit effort in prawn and scallop fisheries. Department of Primary Industries and Fisheries, Fisheries Research and Development Corporation (FRDC), Queensland, Final Report 1999/120.

Ordines, F., Massuti, S., Guijarro, B., and Mas, R. (2006). Diamond vs. square mesh codend in a mulit-species trawl fishery of the western Mediterranean: effects on catch composition, yield, size selectivity and discards. Aquatic Living Resources 19, 329-338. doi:10.1051/ALR:2007003

Pascoe, S. (1997). Bycatch management and the economics of discarding. FAO Fisheries Technical Paper 370.

Robins, J. B. (1995). Estimated catch and mortality of sea turtles from the East Coast Otter Trawl Fishery of Queensland, Australia. Biological Conservation 74, 157-167. doi:10.1016/0006-3207(95)00025-Y

Robins, J. B., and Courtney, A. J. (1998). Status report on bycatch within the Queensland trawl fishery. In 'Establishing Meaningful Targets for Bycatch Reduction in Australian Fisheries, 24-25 September 1998, Hobart'. (Eds C. Buxton and S. Eayrs.) pp. 24-45. (Australian Society for Fish Biology: Sydney.)

Robins, J., Campbell, M., and McGilvray, J. (1999). Reducing prawn-trawl bycatch in Australia: An overview and an example from Queensland. Marine Fisheries Review 61, 46-55.

Ruello, N. V. (1975). An historical review and annotated bibliography of prawns and the prawning industry in Australia. In 'First Australian National Prawn Seminar, 22-27 November, 1973, Maroochydore'. (Ed. P. C. Young.) pp. 305-341. (Australian Government Publishing Service, Canberra.)

Sarda, F., Bahamon, N., Moli, B., and Sarda-Palomera, F. (2006). The use of a square mesh codend and sorting grids to reduce catches of young fish and improve sustainability in a multispecies bottom trawl fishery in the Mediterranean. Scientia Marina 70, 347-353.

Stergiou, K. I., Petrakis, G., and Politou, C. (1997). Size selectivity of diamond and square mesh cod-ends for Nephrops norvegicus in the Aegean Sea. Fisheries Research 29, 203-209. doi:10.1016/S0165 7836(96)00542-5

Sterling, D. J. (2005). Modelling the physics of prawn trawling for fisheries management. Ph.D. Thesis, Curtin University of Technology, Perth.

Stobutzki, I., Miller, M., Jones, P., and Salini, J. (2001). Bycatch diversity and variation in a tropical Australian penaeid fishery; the implications for monitoring. Fisheries Research 53, 283-301. doi:10.1016/S01657836(00)00273-3

Suuronen, P., and Millar, R. B. (1992). Size selectivity of diamond and square mesh codends in pelagic herring trawls - only small herring will notice 
the difference. Canadian Journal of Fisheries and Aquatic Sciences 49, 2104-2117.

Thorsteinsson, G. (1992). The use of square mesh codends in the Icelandic shrimp (Pandalus borealis) fishery. Fisheries Research 13, 255-266. doi:10.1016/0165-7836(92)90080-D

Veale, L. O., Hill, A. S., Hawkins, S. J., and Brand, A. R. (2001). Distribution and damage to the by-catch assemblages of the northern Irish Sea scallop dredge fisheries. Journal of the Marine Biological Association of the United Kingdom 81, 85-96. doi:10.1017/S0025315401003435

Wassenberg, T. J., and Hill, B. (1993). Selection of the appropriate duration of experiments to measure the survival of animals discarded from trawlers. Fisheries Research 17, 343-352. doi:10.1016/0165-7836(93) 90134-S
Watson, R. A., and Goeden, G. (1989). Temporal and spatial zonation of the demersal trawl fauna of the central Great Barrier Reef. Memoirs of the Queensland Museum 27, 611-620.

Watson, R. A., Dredge, M. L. C., and Mayer, D. G. (1990). Spatial and seasonal variation in demersal trawl fauna associated with a prawn fishery on the central Great Barrier Reef, Australia.Australian Journal of Marine and Freshwater Research 41, 65-77. doi:10.1071/MF9900065

Williams, L. E. (2002). Queensland's fisheries resources: current condition and recent trends 1988-2000. Department of Primary Industries, Queensland Department of Primary Industries, Information Series QI02012.

Manuscript received 5 March 2008, accepted 30 June 2008 